\title{
A Proposed Conceptual Framework for Blockchain Technology in Halal Food Product Verification
}

\author{
Nuraslina Zainal Abidin', Dr. Firdaus Fanny Putera Perdana ${ }^{2}$
}

\author{
${ }^{1}$ Chief Executive Officer, Innovation Associates Consulting Sdn. Bhd., Kuala Lumpur, Malaysia \\ 2Consultant, Innovation Associates Consulting Sdn. Bhd., Kuala Lumpur, Malaysia
}

\begin{abstract}
Despite rooted from Islamic needs, Halal certification also attracts both Muslims and non-Muslims. In fact, the non-Muslim players are the ones dominating the industry. It is widely known that Halal food chain is quite vulnerable due to complications in maintaining Halal integrity, the necessity to prevent doubtful materials, lack of control of food norms, and the importance to retain high quality. The presence of Halal certification is a form of consumer protection and therefore, the integrity of Halal certification must be carefully monitored. There are some Halal violation cases and this can potentially affect the reputation of the Halal food products. Therefore, it is important to develop a system that integrates a verifiable, open, and safe shared database that is not run by a centralised operator. Blockchain technology is the one that offers such. The study presents a conceptual framework for blockchain technology for Halal product verification for manufactured food products. The results are desired to help the food industry players in maintaining a system that can improve the transparency and the integrity of their Halal food chain. The system also intends to ensure the affordability and accessibility of Halal certification for as many industry players as possible as blockchain technology is believed to remove the complications in the certification process and reduce paperwork related cost.
\end{abstract}

Keywords: blockchain; halal supply chain; halal certification; food verification; halal industry; technology solutions

Received: 30th November 2019

Accepted: 27th Marc 2020

Published Online: 24th April 2020
${ }^{\star}$ Correspondence:

Nuraslina Zainal Abidin, Innovation Associates Consulting Sdn. Bhd., Kuala Lumpur, Malaysia; nuraslina@theiac.com. Firdaus Fanny Putera Perdana, Innovation Associates Consulting Sdn. Bhd., Kuala Lumpur, Malaysia; firdaus.f@theiac.com.

Citation: Abidin NZ, and Perdana FFP. A proposed conceptual framework for blockchain technology in Halal food product verification. J Halal Ind Serv 2020; 3(Special Issue): a0000079. https://doi.org/10.3687/jhis.a0000079

\section{Introduction}

Despite rooted from the needs of Muslim consumers to fulfil their religious needs, the Halal industry has proved to attract non-Muslim consumers and non-Muslim players as well. It is no longer seen only from its religious point of view, and the Halal concept is also seen as a system that embraces quality assurance and lifestyle choice (Lada, Tanakinjal, \& Amin, 2010). Islam is known as a religion with the highest level of growth in the world. In 2017, it was estimated that there were more than 1.8 billion Muslims all over the world making it the second-largest religion behind Christianity. Due to the high birth rates of 2.7 children per family, it is projected that Islam will be the number one religion on earth in fifty years' time (Pew Research Center, 2017). With this situation, it is believed that the demand towards Halal products will continuously grow and currently, the Halal industry is valued around 2.1 billion USD. It is expected to reach 3 trillion USD by the year 2023 (Shahbandeh, 2019).

Halal food chains are known to be quite vulnerable mainly due to complications in maintaining Halal integrity, the necessity to prevent doubtful materials, lack of control of food norms, and the importance to retain high quality (Tieman \& Darun, 2018). Halal food chain issues mainly include cross-contamination, Halal counterfeiting, Halal fraud, logistic issues and no development towards a standardised Halal standard that is applicable around the world. It is also important to note that the Halal industry is dominated by the non-Muslim players as $80 \%$ of the system is controlled by non-Muslim majority countries (Power, 2008). Nestle, KFC, McDonald's, Tesco, and Carrefour are some of the key players in the Halal industry (Kassim, 2010). Around $20 \%$ of the budget of Muslim consumers are spent for meat purchase and the majority of the Halal meat (65\%) comes from non-Muslim majority countries like New Zealand, Australia, Brazil, and India (Al-Jazeera, 2017). The total export values of meat from Brazil are estimated to be around 6.5 billion USD (Riaz \& Chaudry, 2004). Back in 2017, there was a case in Brazil regarding food fraud scandal and this situation leads to a question about the integrity of Halal meat exported to the Organization of Islamic Cooperation (OIC) countries (Alim, 2017).

Halal risk and reputation management need to be maintained to ensure the trust of Halal consumers around the world. However, the lack of authenticity and inaccuracy is a huge issue that can hurt the integrity of the Halal supply chain. As the Halal food chain issues continue to spread, it is important to find a system that is potentially able to prevent such things. The blockchain concept integrates a verifiable, open, and safe shared database system that is not run by a centralised operator. The incorporation of Blockchain technology can potentially improve transparency in every single process (Tieman \& Darun, 2018).

The paper presents a conceptual framework of Halal food chain verification for the manufactured food products. The framework is hoped to assist the food industry players in designing a system that can improve the transparency and the integrity of their Halal food chain. The developed system is expected to speed up the Halal certification process, and the transparency of the system allows the Muslim consumers to have a higher level of trust towards the products. 


\section{Literature Review}

\section{Challenges in the Halal Food Industry}

It was claimed that research and development of new products are still somehow limited. Therefore, the presence of Halal-certified products around the world is quite minimal. Chances are high that the Muslim consumers in the non-Muslim majority countries will have difficulty to find Halal products for their consumption. Eventually, they have to resort to ingredient checking towards the products and those without proper knowledge may not notice the presence of Subhah (doubtful) materials or even Haram content inside the products. Not only that, but some manufacturers also deliberately hide some ingredients behind the trivial names and this practice makes it even more difficult for the Muslim consumers to confirm the Halal status of the products (Adams, 2007).

Halal supply chain involves farm to fork processes and it is crucial to maintain the integrity of every single aspect. The halal industry is hugely controlled $(80 \%)$ by the non-Muslim players and this is quite alarming as there are potentials that the industry players do not have proper knowledge regarding the process and the integrity. Some Muslim consumers also question their integrity in doing such business process as they are not necessarily the ones at stake when it comes to the final product. The lack of supply in Halal raw materials and Halal meat also highly affects the backbone of Halal industry (Bohari, Hin, \& Fuad, 2013). One of the most crucial issues in the Halal industry is authenticity and accuracy in the data of the Halal products (Tieman \& Darun, 2018). Halal food chain processes are highly challenged by cross-contamination, Halal counterfeiting, Halal fraud, logistic issues, and unstandardised Halal standards.

The existence of many Islamic teachings around the world leads to the difficulty in standardising Halal standards. Therefore, Halal certification systems developed are mainly not recognised globally. Halal certification bodies usually do not recognise each other as they have different practices. JAKIM (Department of Islamic Development Malaysia) and MUI (Indonesian Ulema Council) list the Halal certification bodies that they recognise and the list changes according to the situations of the recognised bodies. However, some Halal logo fraud cases also haunt the Halal industry lately and this issue needs to be soon addressed. It is also important to note that the Halal status of cargo is not communicated on cargo labels, freight documents, and in ICT systems (Tieman \& Darun, 2018). The cargo can easily be used for transporting non-Halal products and Halal products at the same time. This can lead to a cross-contamination issue.

Another issue in the Halal industry is the slow loan process and this especially affects the small and medium-sized enterprises (SMEs). This puts an effect on the affordability of the Halal certification process, and some of the SMEs are discouraged and cannot ensure the availability of Halal certification in their products (Majid, Abidin, Majid, \& Chik, 2015). These SMEs cannot compete with the major players as it is hard for them to gain trust from the consumers. Applying for Halal certification might be considered cheap, but the implementation of Halal certification involves a lot of resources and financial issue is a major contribution to the failure of implementation.

\section{Halal Food Chain Violation Cases}

To ensure that a Halal product is achieved, the Halal supply chain must be accordingly monitored. However, due to the complicated and lengthy processes, some parts of Halal food chain can easily be violated by the irresponsible players. Brazil is one of the most important key suppliers of meat for the OIC countries and the export is valued at around 6.5 billion USD
(Riaz \& Chaudry, 2004). However, since Brazil is a non-Muslim majority country, it is quite difficult to control the integrity of the Halal supply chain in the country. It was reported by Reuters a food fraud issue in Brazil and this involved bribery towards the politicians as well as the food inspectors (Alim, 2017). The food inspectors and politicians were bribed to ensure that the industry can get away with their unhygienic practices. It is hard to identify how much Halal food is involved in this travesty. The total of meat exports in Brazil was 12 billion USD in 2016, both for Halal and non-Halal sections. Approximately $25 \%$ of beef exports and $50 \%$ of poultry exports in Brazil are Halal (Alim, 2017). A Malaysian study discussed the food from Middle Eastern and North Africa and it conducted an investigation into some Arab shops around Klang Valley area. They discovered that some of the products with Arabic writings were manufactured in countries like the Netherlands, China, Spain, India, Vietnam, and Thailand (Perdana, Jan, Altunişik, Jaswir, \& Kartika, 2019). Since the products were produced in non-Muslim countries, these can be exposed to cross-contamination or practices that are not in line with the Shariah Law (Perdana, Jan, Altunişik, Jaswir, \& Kartika, n.d.).

In Malaysia, Halal counterfeiting cases were identified by the Domestic Trade and Consumer Affairs Ministry in 2018. Around 41 cases were identified, and 17 million products involved in the fake Halal logo cases were seized. Datuk Muez Abd. Aziz reported that Halal counterfeiting cases are crucial to be solved as the Halal food industry in Malaysia is estimated to be valued around 560 million USD (Reduan \& Anwar, 2018). A meat supplier in the UK that claimed to sell Halal meat was arrested for a food fraud case. The food fraud was identified after the laboratory test indicated that cheaper beef cut was found in the lamb meat sold by the supplier. The supplier also put a Halal logo at the shop and it had never been certified before (Johari, 2010). McDonald's in the USA discontinued the production of Halal chicken nuggets and chicken sandwiches at two of its chains. It was accused of false advertisement regarding Halal chicken and a lawsuit was filed for that. McDonald's had to pay 700,000 USD for the case but it denied any wrongdoing in the situation (Sacirbey, 2013). Aossey, the founding father of Midamar Corporation (a US company that specialises in the Halal food trade), was arrested for mislabelling cases that involved the export of beef that was not in accordance with Indonesian and Malaysian Halal standard. The man himself is one of the pioneers of Halal trade in the US (The Jakarta Post, 2016).

Cross-contamination is a huge issue that disrupts the integrity of the Halal supply chain. Doosti, Ghasemi, \& Rahimi (2014) conducted a study in Iran and unlawful meats like poultry, pig, donkey, and horse meat were found in the 17 meat products studied. In 2017, pork meat was found in the four containers that were designated to carry goat meat. The four containers were seized by MAQIS (Malaysian Quarantine Inspection Services) and allegedly there were 74 more containers with similar content. It was believed that some of those were sold to the Malaysian consumers already. The containers were owned by a local company claiming to have a Malaysian Halal certification. However, upon investigation, it was found that the company was not registered to the Halal certification body. The company was charged for misusing the Halal logo in its business (Suhaini, 2017).

Despite careful attempts in complying with the Halal certification requirements, some companies may have to experience failures in the system, and this can lead to violations. Halal certification of High-5 bakery in Nilai was withdrawn as it was found that the company involved unsanitary process, had an issue regarding the employment of illegal workers, and most importantly cooking oil without Halal certification was found during an audit (The Star, 2012). Two of the Cadbury products namely Cadbury Dairy Milk Roast Almond and Cadbury Dairy Milk Hazelnut had a Halal integrity issue as the Malaysia Health 
Minister found a trace of porcine (pig) DNA in those products (Halalmedia, 2014). Eventually, JAKIM conducted a test and the results indicated that Cadbury complied with Halal certification requirements. It was later announced to the Muslims that Cadbury was safe for consumption (EatHalal, 2014; Reuters, 2014).

\section{The Technology to Solve the Halal Food Issues}

The presence of Halal certification is crucial for the Muslim consumers and even to them, it is more important than International Standardized Organization (ISO) certification (Shafie \& Othman, 2006). Halal certification is a form of assurance that protects their religious needs, and the integrity of Halal certification must be maintained. As Halal products are also consumed by the non-Muslim consumers, it is also imperative that the Halal certification bodies and industry players maintain the reputation and the trust so they can retain the consumers. However, the Halal industry also deals with so many inaccuracy and inauthenticity issues lately. It is quite difficult to control the whole system as not everyone has access to the information. All the stakeholders and industry players have their own in-house ledgers that store their information. This is where the issues may arise as the current system does not really embrace transparency. Transparency is the key to a successful Halal food chain, and the presence of transparency will improve both authenticity and trust of a Halal certified product. Blockchain itself is a technology that allows a shared database that is equipped with an open, safe, and verifiable system. The implementation of blockchain also does not require the presence of a central operator and thus, the information flow cannot be easily manipulated.

One of the most sensitive issues in the Halal industry is the integrity of the food supply chain. Halal food supply chain issues mainly include cross-contamination, Halal counterfeiting, Halal fraud, logistic issues and no development towards a standardised Halal standard that is applicable around the world. There was an E. coli outbreak back then in 2018 and it took so long for the Walmart to identify which batches of romaine lettuce that contained E. coli bacteria. The blockchain technology could have prevented the time wasted and complications during the identification as the information would have been accessible for everyone. Malaysia Health Minister found a trace of porcine (pig) DNA in Cadbury Dairy Milk Roast Almond and Cadbury Dairy Milk Hazelnut. The Muslim consumers in Malaysia lost their trust in Cadbury for some time and it took a while for the company to eventually gain their trust again. JAKIM eventually announced that the company complied with the Halal certification requirements, but the damage caused by issues from certain batches could have cost Cadbury the reputation. The implementation of blockchain would have directed the company to the tainted products right away and the issues would have been solved in no time. JAKIM could have easily confirmed the Halal status of everything else as the presence of blockchain technology would have shared all the information required.

\section{Overview of Blockchain Technology}

Initially, blockchain technology was destined to solve a problem in the financial sector (Zheng, Xie, Dai, Chen, \& Wang, 2017). Blockchain can be defined as a secure ledger that serves every transaction. Each ledger is attributed to every involved party within a particular distributed network of computers. Everything involved in every transaction is accordingly archived and recorded, and this is to ensure the integrity and authenticity of all the distributed information. The system is possible due to the distributed consensus mechanism.

Blockchain resembles our DNA structure as it is not centralised at a certain place. It is accordingly distributed on var- ious servers available in the world (Tieman \& Darun, 2018). All the blockchains are ciphered, and they are integrated into the distributed blockchains. This allows them to be a public ledger that everyone finds trustworthy. Every single user has access to check the value, but no user is able to control. Smart contracts are contracts between all involved parties that serve to ensure compliance in each node (Kiayias, Russell, David, \& Oliynykov, 2017). The integration between distributed ledger system and smart contracts will allow an improved system for the Halal supply chain. For the blockchain system in general, please see Figure 1.

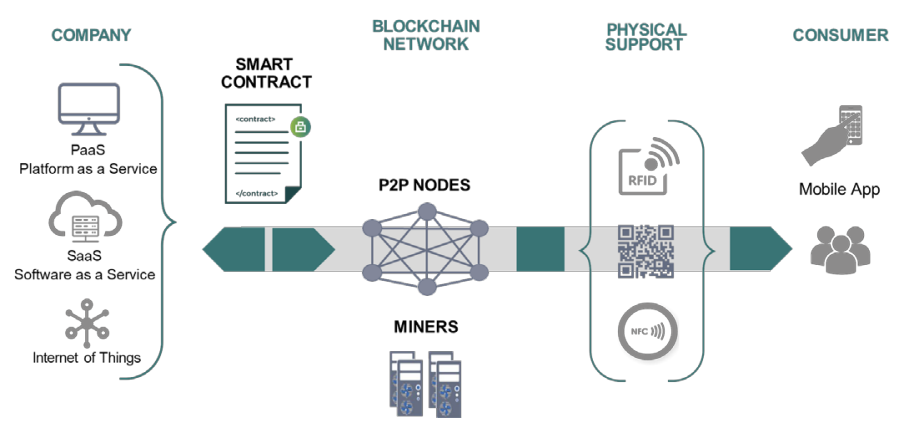

Figure 1. General Blockchain System.

The information in all blockchain nodes can be presented in any size and form such as video, documents, and images. Every single block attributed to a blockchain network is bound to save some information along with the hash of its preceding block. A hash is defined as a special mathematical code which is attributed to a certain block. Once there is a modification in the information inside the block, a modification inside the hash will occur as well. The system allows the connection of many blocks through a special hash code and this ensures the security of blockchain (Kiayias et al., 2017). With the utilisation of a mobile app and website, the information available can be open to the public for the entire supply chain, shared with only certain users in the supply chain system or reserved. The benefits of blockchain include improved trust, chain integrity, transparency and performance optimisation (Axfoundation, SKL Kommentus, Swedish county councils and regions, Martin \& Servera, \& Kairos Future, 2017). The usage of blockchain allows the consumers to validate the integrity of the products and therefore, it will retain their trust in using the products. In terms of chain integrity, it allows automatic alignment of market requirements to a supply chain scenario (Tripoli \& Schmidhuber, 2018). Apart from that, blockchain improves transparency in the sense of a better audit system and effective isolation towards important issues (Yiannas, 2018). Blockchain implementation can also be a system that can gauge the performance of every party involved, thus identification towards the optimisation in the system will be possible (Caro, Ali, Vecchio, \& Giaffreda, 2018).

\section{Implementation of Blockchain Technology in The Food Industry}

As it progresses, many potentials are unlocked and the versatility of blockchain technology allows it to be implemented in many different industries (Axfoundation et al., 2017; Lin, Shen, Zhang, \& Chai, 2018; Mathisen, 2018; A Rejeb, 2018; Abderahman Rejeb, 2018; Verhoeven, Sinn, \& Herden, 2018; Yiannas, 2018; Zubaidi \& Abdullah, 2017). The food industry is one of the sectors that has been actively developing blockchain technology, especially in the traceability department. The World Wildlife Fund (WWF) in Australia, Fiji and New Zealand used a blockchain technology to trace and track tuna fishing journey from "bait to plate". The project was intended to prevent illegal fishing and violation of human rights in the industry (Visser \& 
Hanich, 2017). A company called AgriDigital utilised blockchain technology for their grain sales. The company settled their very first sale in December 2016 and 23.46 tonnes of grain were sold with the help of blockchain (ICT4Ag, 2017). The company has since elevated efficient and trustworthy agricultural supply chain to the next level (AgriDigital, 2017). Food contamination is one of the major contributors in American health issues as around 48 million of Americans were found to be sick and 3,000 were to die each year due to that particular issue (CDC, 2018). This situation inspired Walmart and Kroger to incorporate blockchain technology in their food supply chain and one of their first pilot studies focused on Mexican mangoes (CB Insights, 2017). Cargill Inc., a giant in agriculture business, incorporates blockchain technology that allows their consumers to trace the origin of their turkeys (Bunge, 2017). The pilot project conducted by the company also involves concerns in their animal welfare (Hendrix Genetics, 2018). The grocer giant from Europe, Carrefour, also involves blockchain technology in their system, and this helps standardise and trace food origins in many categories, including dairy products, vegetables, fruits, fish, and meat (Love \& Somerville, 2018)

\section{Framework of Blockchain in the Halal Industry}

\section{Halal Food Chain and Process Flow}

The Halal food supply chain is defined as a series of the farm-to-fork process involving Halal food supply and the Halal integrity of all the processes is accordingly maintained. Bahrudin, Illyas, and Desa (2011) defined the Halal food supply chain as management towards the procurement, transportation, storage and handling of livestock, parts, materials, as well as semi-finished food inventory. The process also manages the non-food and food-related information as well as the documentation flows in the supply chain. All the processes are conducted according to Sharia Law. Based on the proposed context, the supply chain of Halal food products includes Transporters, Suppliers, Manufacturing Plants, Warehouses, Wholesalers, Distributors, Retailers, and Final Consumers (see Figure 2).

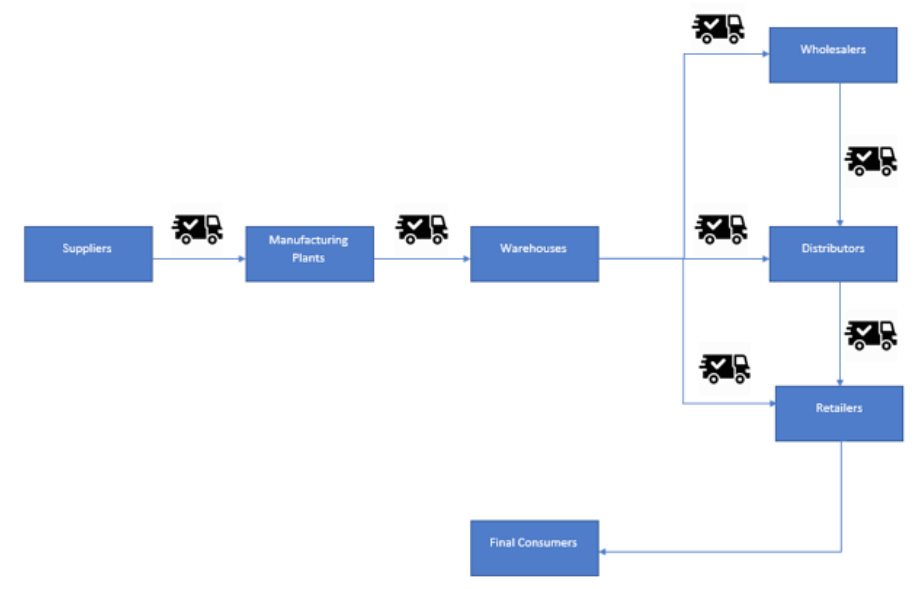

Figure 2. General Halal Food Products Supply Chain.

The process starts with the Suppliers and at this point, it is very critical to ensure the Halal status of the raw materials, food additives, and packaging materials (Ab Talib, Abdul Hamid, \& Zulfakar, 2015). If an animal is involved in the raw materials, food additives or packaging materials, it is important that the animals are being fed with hygienic, good quality, and nutritious animal feed. If genetic modification process is present, it must be ensured that no Haram substances are involved in the process. They also must be slaughtered according to Shariah Law. Any food additives that involve khamr or other Haram substances must also be avoided. The Halal certification of the suppliers must also be carefully monitored, especially the information regarding the expiry date (Soon, Chandia, \& Regenstein, 2016).

For the transporters point, it is important to understand the segregation level of the truck in case non-Halal products are also transported using the same truck. If the truck area was previously used for transporting non-Halal products, Samak process must also be performed before loading the truck with the Halal products. At the manufacturing plants, the production process must be conducted in the Halal only line. Halal equipment and worker practice must follow the hygiene requirement that is in line with Shariah Law. At the warehouses, it is crucial to monitor segregation between Halal products and non-Halal products, storage conditions (temperature, impacts, humidity), and adequate control of contamination with non-Halal products. The products from the Warehouses are later transferred to Wholesalers, Distributors and Retailers. It is also crucial to understand the segregation level between Halal products and non-Halal products, storage conditions (temperature, impacts, humidity), and adequate control of contamination with non-Halal products (Zailani, Arrifin, Wahid, Othman, \& Fernando, 2010).

\section{Proposed Framework for Blockchain in the Halal Food Chain}

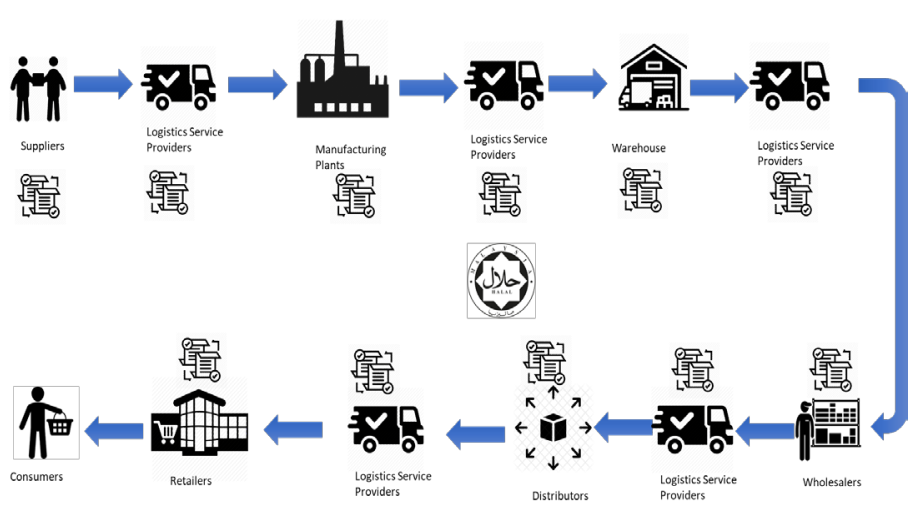

Figure 3. Halal Food Chain without Blockchain Technology.

The implementation of blockchain technology in the Halal industry is desired to achieve more reliability in the supply chain data and improve the trust level in the supply chain processes. Blockchain can also potentially improve the efficiency of the processes that include all the players from the source point to the final consumer point. The confidence level of the consumers is potentially improved as blockchain technology embraces transparency and security. Blockchain technology also offers an automated system that can lead to time reduction in solving certain problems. Problems that are solved in a short period of time will help Halal certified products minimise the damage of their brand image or reputation. Most importantly, blockchain technology allows globalisation towards the Halal industry. The technology integrates all the different Islamic teachings and Halal certification requirements around the world. Fatwas (local religious rulings) and local customs can also be included in the blockchain system. With the integrated system, it is hoped that we can have a Halal certification system that can be globally accepted. Without blockchain technology, the information will be stored individually in the in-house ledger of every party (Figure 3). With the help of blockchain technology, all the parties can access the available information (Figure 4). 


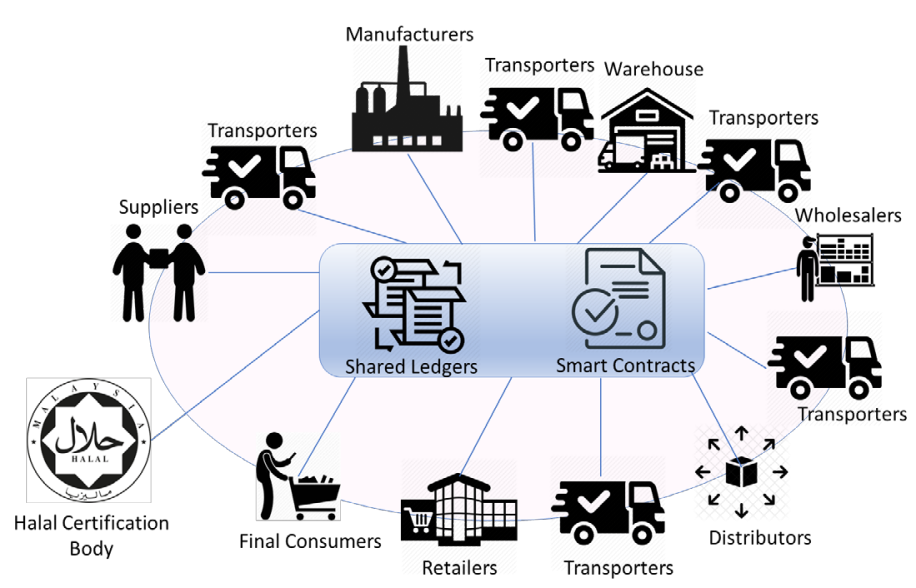

Figure 4. Halal Food Chain with Blockchain Technology.

To ensure smooth implementation of Blockchain technology in the Halal industry, there are many requirements that need consideration. Identification numbers will be placed on the animals at the farm and those identification numbers will be saved in a certain ledger. There will be a monitoring system for the animals, and it covers their living conditions and food intake. At the slaughterhouses, the health of the animals will be carefully checked, and there will be a report from an esteemed veterinarian to validate the health conditions of the animals. Upon that, various timestamps will be added to the blockchain, and this is intended to understand the cut of meat from the animal and the way the animals were treated while they were at the slaughterhouse. The data will be used as a reference to ensure the Halal integrity of the animal/meat.

DNA sensor can also be incorporated to ensure that Halal meat is up to standard upon being processed. The meat is packed with smart packaging, and this will allow a monitoring process that can track the logistics of the product from factory to supermarket or restaurant. The smart packaging and the sensors can be integrated with blockchain technology to monitor the Halal integrity of the products. Apart from that, it is also crucial to store environmental data attributed to the locations in the blockchain system.

Having all the data stored in the available ledger, the stakeholders and the consumers can have access to the information regarding Halal integrity. They can either access the information through mobile application or website. Blockchain technology is also important for the governments as it offers solutions related to import controls. The implementation of blockchain allows improvement in the regulatory compliance standards.

Once blockchain receives the information from various stakeholders across the supply chain, it is also possible to monitor the data related to legal and tax. Both B2C (Business to Consumer) and B2B (Business to Business) relations can benefit from blockchain implementation as it is a device that ensures a higher level of transparency and authenticity assurance. Consumers will have a higher level of confidence as they will be able to trace the origins of the ingredients as well as the way the animals were treated during the slaughtering process. Eventually, the implementation of blockchain technology is served as a platform for Halal industry players to enhance responsibility and transparency in the process. Improvement in both transparency and responsibility means higher quality for Halal products available in the market.

The idea of blockchain technology developed for Halal chain is to obtain information regarding the Halal certification body that issues the Halal certification towards the products, the country of origin, the Madhabs that can accept the Halal standards/requirements, commence date of Halal certification, the expiry date of Halal certification, recognition from JAKIM as well as recognition from other Halal certification bodies. All the Madhab requirements are integrated, and some products can be acceptable for more than one single Madhab. The information regarding Halal certification bodies is hoped to create a data pool that incorporates as many registered Halal certification bodies as possible. With the information, Halal certified products that are only locally recognised can further their presence in the national or even international market. This will help increase their sales and revenues and by achieving so, they will be more interested to develop more products in the future. The framework of blockchain technology for Halal food chain flow can be seen in Figure 5 and the explanation of each node can be seen in Table 1 below.

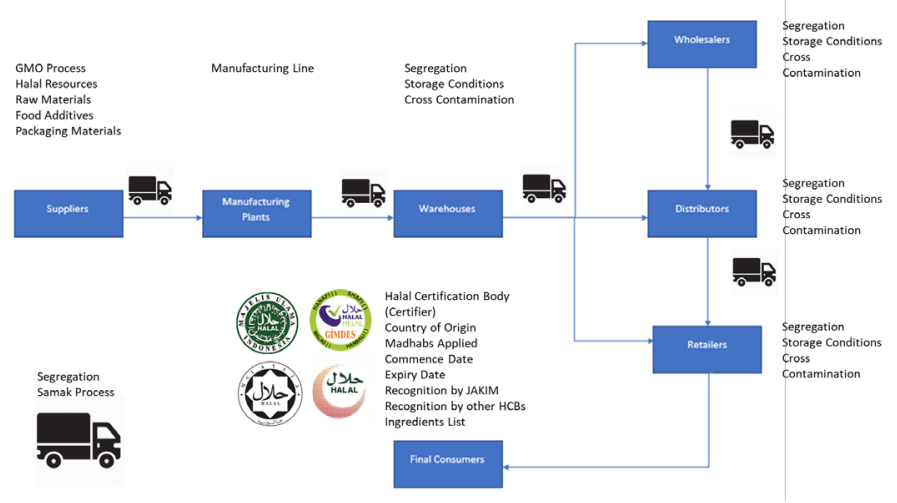

Figure 5. Tracked Items at Halal Chain Point.

Many food industry players in the OIC countries are most likely not Halal certified as most of these countries apply the Kullu Halal concept. The Kullu Halal concept means everything is Halal unless stated otherwise (Cochrane, 2016). Despite heavily applied, these countries also import ingredients from non-Muslim countries and some of them are even animal-based (Latif, Mohamed, Sharifuddin, \& Mahir, 2014). With the blockchain technology, the integrated system for Halal certification requirements will speed up the Halal certification process in the future. This will eliminate the complications in the certification process as well as potential cost reduction in the documentation aspect. The Muslim consumers, especially the ones living in non-Muslim majority countries, will also take advantage of the system by having more trust towards the products they consume as blockchain technology improves transparency in every single point.

Table 1. Items Controlled by Blockchain Technology.

\begin{tabular}{|c|l|l|}
\hline No. & Process & Controlled Items \\
\hline \multirow{2}{*}{1} & \multirow{4}{*}{ Suppliers } & Halal certified raw materials \\
\cline { 3 - 3 } & & Halal certified food additives \\
\cline { 3 - 3 } 2 & $\begin{array}{l}\text { Manufacturing } \\
\text { Plants }\end{array}$ & $\begin{array}{l}\text { Halal certified packaging materials } \\
\text { dedicated machinery and equipment }\end{array}$ \\
\hline \multirow{2}{*}{3} & \multirow{2}{*}{ Warehouses } & $\begin{array}{l}\text { Proper segregation between Halal } \\
\text { products and non-Halal products }\end{array}$ \\
\cline { 3 - 4 } & $\begin{array}{l}\text { Proper storage conditions } \\
\text { (temperature, impacts, humidity) }\end{array}$ \\
\cline { 3 - 4 } & & $\begin{array}{l}\text { Adequate control of contamination } \\
\text { with non-Halal products }\end{array}$ \\
\hline
\end{tabular}




\begin{tabular}{|c|c|c|}
\hline \multirow[t]{2}{*}{4} & \multirow[t]{2}{*}{ Transportation } & $\begin{array}{l}\text { Samak process if the truck was used } \\
\text { to transport non-Halal meat }\end{array}$ \\
\hline & & $\begin{array}{l}\text { Segregation between Halal meat and } \\
\text { non-Halal meat }\end{array}$ \\
\hline \multirow{3}{*}{5} & \multirow{3}{*}{ Wholesalers } & $\begin{array}{l}\text { Proper segregation between Halal } \\
\text { products and non-Halal products }\end{array}$ \\
\hline & & $\begin{array}{l}\text { Proper storage conditions } \\
\text { (temperature, impacts, humidity) }\end{array}$ \\
\hline & & $\begin{array}{l}\text { Adequate control of contamination } \\
\text { with non-Halal products }\end{array}$ \\
\hline \multirow{3}{*}{6} & \multirow{3}{*}{ Distributors } & $\begin{array}{l}\text { Proper segregation between Halal } \\
\text { products and non-Halal products }\end{array}$ \\
\hline & & $\begin{array}{l}\text { Proper storage conditions } \\
\text { (temperature, impacts, humidity) }\end{array}$ \\
\hline & & $\begin{array}{l}\text { Adequate control of contamination } \\
\text { with non-Halal products }\end{array}$ \\
\hline \multirow{3}{*}{7} & \multirow{3}{*}{ Retailers } & $\begin{array}{l}\text { Proper segregation between Halal } \\
\text { products and non-Halal products }\end{array}$ \\
\hline & & $\begin{array}{l}\text { Proper storage conditions } \\
\text { (temperature, impacts, humidity) }\end{array}$ \\
\hline & & $\begin{array}{l}\text { Adequate control of contamination } \\
\text { with non-Halal products }\end{array}$ \\
\hline \multirow{6}{*}{8} & \multirow{6}{*}{$\begin{array}{l}\text { Halal } \\
\text { Certification } \\
\text { Bodies }\end{array}$} & $\begin{array}{l}\text { The name of Halal Certification } \\
\text { Body (HCB) that issues the } \\
\text { certification }\end{array}$ \\
\hline & & $\begin{array}{l}\text { The country where the product } \\
\text { originated }\end{array}$ \\
\hline & & $\begin{array}{l}\text { List of madhab followers that can } \\
\text { accept the Halal practices/Halal } \\
\text { standards }\end{array}$ \\
\hline & & $\begin{array}{l}\text { The commence date issued by the } \\
\text { HCB }\end{array}$ \\
\hline & & The expiry date issued by the $\mathrm{HCB}$ \\
\hline & & $\begin{array}{l}\text { The Halal Certification Bodies that } \\
\text { recognise this particular product }\end{array}$ \\
\hline
\end{tabular}

\section{Conflict of Interest}

in this work.

The authors declare that there is no conflict of interest

\section{References}

Ab Talib, M. S., Abdul Hamid, A. B., \& Zulfakar, M. H. (2015). Halal supply chain critical success factors: A literature review. Journal of Islamic Marketing, 6(1), 44-71. Retrieved from https://doi.org/10.1108/JIMA-07-2013-0049

Adams, M. (2007). How food manufacturers trick consumers with deceptive ingredients lists. Retrieved from Natural News.com website: http://www.naturalnews.com/021929_ groceries_food_products.html

AgriDigital. (2017). We're building blockchain-based solutions for global agricultural supply chains. Retrieved from https://www.agridigital.io/blockchain

Al-Jazeera. (2017). Where does halal meat come from? Retrieved from https://www.aljazeera.com/indepth/interactive/2017/11/171126063915359.html

Alim, E. A. (2017). UPDATE-Brazil food fraud scandal: How much halal exports are in the mix?

Axfoundation, SKL Kommentus, Swedish county councils and regions, Martin \& Servera, \& Kairos Future. (2017). Blockchain use cases for food traceability and control: a study to identify the potential benefits from using blockchain technology for food traceability and control [PDF file]. Retrieved from http://axfoundation.se/wp-content/uploads/2017/12/Blockchain-use-cases-for-food-trackingand-control-dig-lätt.pdf

Bahrudin, S. S. M., Illyas, M. I., \& Desa, M. I. (2011). Tracking and tracing technology for halal product integrity over the supply chain. Proceedings of the 2011 International Conference on Electrical Engineering and Informatics, ICEEI 2011, (July). https://doi.org/10.1109/ICEEI.2011.6021678

the Halal food chain as well as the violation cases that have occurred in the past few years. Despite the supply chain applied in the system, monitoring every single step can be quite challenging. It is also important to note that implementing Blockchain technology can be somewhat challenging to the industry. Some of the challenges include implementation issues, regulatory issues, potential security threats, uncertain ROI, no available use case in the Halal industry, and concerns regarding sensitive information. Blockchain technology is quite new, and people's awareness of the importance and benefits of it is quite low. It is important to educate the Halal industry players regarding the Blockchain technology and what it can potentially offer to their business model. The incorporation of blockchain technology is hoped to overcome the issues in the Halal food chain. The paper also presents a framework that incorporates blockchain technology in the Halal food chain. The proposed framework is hoped to help the food industry players in maintaining a system that can improve the transparency and the integrity of their Halal food chain. Apart from that, the developed system is expected to speed up the Halal certification process and eventually it will lead to the affordability of the certification process. The transparency of the system allows the Muslim consumers to have a higher level of trust towards the products and this is a form of consumer protection for them.

Bohari, A. M., Hin, C. W., \& Fuad, N. (2013). The competitiveness of halal food industry in Malaysia : A SWOT-ICT analysis. Journal of Society and Space, 1(1), 1-9.

Bunge, J. (2017). Latest use for a Bitcoin technology: Tracing Turkeys from farm to table. Retrieved from https://www.wsj. com/articles/latest-use-for-a-bitcoin- technology-tracing-turkeys- from-farm-to-table-1508923801

Caro, M. P., Ali, M. S., Vecchio, M., et al. (2018). Blockchain-based traceability in Agri-Food supply chain management: A practical implementation. 2018 IoT Vertical and Topical Summit on Agriculture - Tuscany, IOT Tuscany 2018, 1-4. https://doi.org/10.1109/IOT-TUSCANY.2018.8373021

CB Insights. (2017). How blockchain could transform food safety. Retrieved from https://www.cbinsights.com/research/ blockchain-grocery-supply-chain/

CDC. (2018). Centers for disease control and prevention. 
Retrieved from https://www.cdc.gov/foodborneburden/2011-foodborne-estimates.html

Cochrane, P. (2016). Lebanon's Halal food sector in need of national-level oversight to boost market confidence and exports. Retrieved from https://www.salaamgateway.com/ en/story/lebanons_halal_food_sector_in_need_of_nationallevel_oversight_to_boost_market_confidence_and exports-SALAAM24092016061614/

Doosti, A., Ghasemi Dehkordi, P., and Rahimi, E. (2014). Molecular assay to fraud identification of meat products. Journal of Food Science and Technology, 51(1), 148-152. Retrieved from https://doi.org/10.1007/s13197-011-0456-3

EatHalal. (2014). Jakim confirm Cadbury Malaysia’s chocolates are Halal.

Halalmedia. (2014). Long-term impact expected for Cadbury over porcine-tainted chocolates.

Hendrix Genetics. (2018). New blockchain project involving turkeys and animal welfare. Retrieved from https://www.hendrix-genetics.com/en/news/new-blockchain- project-involving-turkeys-and-animal-welfare/

ICT4Ag. (2017). Perspectives for ICT and Agribusiness in ACP countries: Start-up financing, $3 D$ printing and blockchain. Retrieved from http://www.fao.org/e- agriculture/events/ cta-workshop-perspectives-ict-and-agribusiness-acpcountries- start-financing-3d-printing-and

Johari, R. E. (2010). Fraud on halal food: More than just food safety at stake.

Kassim, A. M. (2010). The global market potential of Halal. International Conference \& Expo on Halal Industry Lahore, Pakistan, 8-14. Retrieved from www.halalrc.org

Kiayias A., Russell A., David B., et al. (2017) Ouroboros: A provably secure proof-of-stake blockchain protocol. In: Katz J., Shacham H. (Eds) Advances in Cryptology - CRYPTO 2017. CRYPTO 2017. Lecture Notes in Computer Science, vol 10401. Springer, Cham.

Lada, S., Tanakinjal, G. H., \& Amin, H. (2010). Predicting intention to choose halal products using theory of reasoned action. International Journal of Islamic and Middle Eastern Finance and Management, 2(1), 66-76. Retrieved from https://doi.org/10.1108/17538390910946276

Latif, I. A., Mohamed, Z., Sharifuddin, J., et al. (2014). A comparative analysis of global Halal certification requirements a comparative analysis of global Halal. Journal of Food Products Marketing, 20(1), 85-101. Retrieved from https://doi. org/10.1080/10454446.2014.921869

Lin, J., Shen, Z., Zhang, A., et al. (2018). Blockchain and IoT based Food traceability for smart agriculture. International Conference on Computational Science and Engineering, 1-6. Retrieved from https://doi.org/10.1145/3265689.3265692

Love, J., \& Somerville, H. (2018). Retailer Carrefour using blockchain to improve checks on food products. Retrieved from https://www.reuters.com/article/us-didi-mexico/chi- nese-uber-rival-didi-launches-in-mexico-recruits-drivers-idUSKCN1HDOPH

Majid, M. A. A., Abidin, I. H. Z., Majid, H. A. M. A., et al. (2015). Issues of Halal food implementation in Malaysia. Journal of Applied Environmental and Biological Sciences Www. Textroad.Com, 5, 50-56.

Mathisen, M. (2018). The application of blockchain technology in norwegian fish supply chains - A case study (Master's Thesis, Norwegian University of Science and Technology, Trondheim, Norway). Retrieved from https://brage.bibsys.no/ xmlui/handle/11250/2561323

Perdana, F. F. P., Jan, M. T., Altunişik, R., et al. (2019). The role of halal certification on purchase intention towards food products from MENA countries: A sem study. Journal of Islamic Monetary Economics and Finance, 5(1), 63-88.

Perdana, F. F. P., Jan, T., Altunişik, R., et al. (n.d.). A research framework of the Halal certification role in purchase intention of Muslim consumers on the food products from Muslim Majority countries in the Middle East and North Africa, 1, 15-28.

Pew Research Center. (2017). The future of the global Muslim population.

Power, C. (2008). Halal goes global.

Reduan, H., and Anwar, M. R. M. (2018). 17 million products seized over use of fake Halal logos.

Rejeb, A. (2018). Addressing healthcare issues in Tunisia with blockchain technology. Acta Technica Jaurinensis, 11(1), 0-00. https://doi.org/10.14513/actatechjaur.v11.n1.000

Rejeb, Abderahman. (2018). Halal meat supply chain traceability based on HACCP, blockchain and internet of things. Acta Technica Jaurinensis, 11(4), 218-247. https://doi. org/10.14513/actatechjaur.v11.n4.467

Reuters. (2014). Malaysia says Cadbury products found not to contain pig DNA. Retrieved from https://www.reuters.com/article/us-malaysia-cadbury/malaysia-sayscadbury-products-found-not-to-contain-pig-dnaidUSKBN0ED08Q20140602

Riaz, M. N., \& Chaudry, M. M. (2004). Halal food production. Boca Raton, FL: CRC Press.

Sacirbey, O. (2013). Concerns rise over halal fraud. Washington, DC.

Shafie, S., \& Othman, M. N. (2006). Halal certification: An international marketing issues and challenges. In Proceeding at the International IFSAM VIII Th World Congress, 28-30.

Shahbandeh, M. (2019). Existing and potential value of Muslim market worldwide in 2017 and 2023 (in billion U.S. dollars).

Soon, J. M., Chandia, M., \& Regenstein, J. Mac. (2016). Halal integrity in the food supply chain. British Food Journal, 119(1), 39-51. 
Suhaini, N. A. (2017, 17 July). 4 kontena daging kambing campur babi dirampas. Berita Harian. Retrieved from https://www. bharian.com.my/berita/nasional/2017/07/303117/4-kontena-daging-kambing-campur-babi-dirampas

The Jakarta Post. (2016, 26 February). Halal foods pioneer sentenced for export fraud to Indonesia, Malaysia. Retrieved from https://www.thejakartapost.com/news/2016/02/26/ halal-foods-pioneer-sentenced-export-fraud-indonesia-malaysia.html

The Star. (2012, 5 March). Alleged irregularities cast doubt on Silver Bird's performance and position, say analysts. Retrieved from https://www.thestar.com.my/business/business-news/2012/03/05/alleged-irregularities-cast-doubt-on-silver-birds-performance-and-position-say-analysts

Tieman, M., \& Darun, M. R. (2018). Leveraging blockchain technology for halal supply chains. Islam and Civilisational Renewal, 8(4), 547-550. Retrieved from https://doi. org/10.12816/0045700

Tripoli, M., \& Schmidhuber, J. (2018). Emerging opportunities for the application of blockchain in the Agri-food industry Agriculture. Food and Agriculture Organization of the United Nations. Retrieved from https://www. researchgate.net/profile/Josef_Schmidhuber/publication/327287235_Emerging_Opportunities_for_the_Application_of_Blockchain_in_the_Agri-food_Industry/ links/5b86ced4299bf1d5a7310c38/Emerging-Opportunities-for-the-Application-of-Blockchain-in-the-

Verhoeven, P., Sinn, F., \& Herden, T. (2018). Examples from blockchain implementations in logistics and supply chain management: Exploring the mindful use of a new technology. Logistics, 2(3), 20. Retrieved from https://doi. org/10.3390/logistics2030020

Visser, C., \& Hanich, Q. A. (2017). How blockchain is strengthening tuna traceability to combat illegal fishing. The Conversation, 1-4.

Yiannas, F. (2018). A new era of food transparency powered by blockchain. Innovations: Technology, Governance, Globalization, 12(1-2), 46-56. Retrieved from https://doi. org/10.1162/inov_a_00266

Zailani, S., Arrifin, Z., Wahid, N. A., et al. (2010). Halal traceability and Halal tracking systems in strengthening Halal food supply chain for food industry in Malaysia (A Review). Journal of Food Technology, 8(3), 74-81. Retrieved from https://doi.org/10.3923/jftech.2010.74.81

Zheng, Z., Xie, S., Dai, H., et al. (2017). An overview of blockchain technology: Architecture, consensus, and future trends. Proceedings - 2017 IEEE 6th International Congress on Big Data, BigData Congress 2017, 557-564. Retrieved from https://doi.org/10.1109/BigDataCongress.2017.85

Zubaidi, I. B., \& Abdullah, A. (2017). Developing a digital currency from an Islamic perspective: Case of blockchain technology. International Business Research, 10(11), 79. Retrieved from https://doi.org/10.5539/ibr.v10n11p79 